\title{
Judith Gautier y su proyecto autobiográfico Mémoires d'un Éléphant blanc, ahora en castellano*
}

\author{
Carmen PÉrez Rodríguez \\ Universidad de Salamanca \\ carmenpro@usal.es \\ ORCID: 0000-0001-8686-4827
}

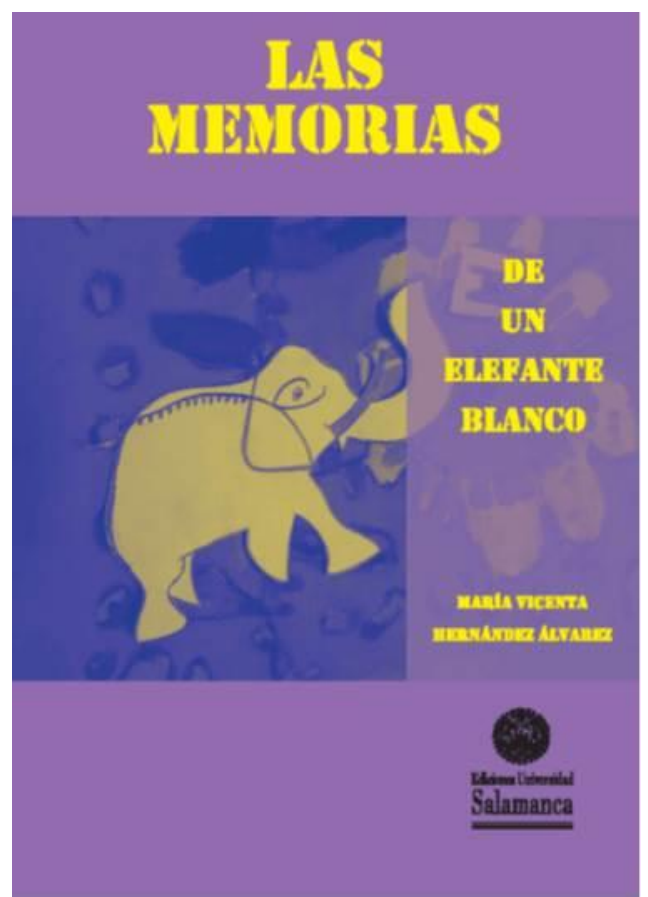

El libro que reseñamos corresponde a la primera traducción al castellano de la obra de Judith Gautier Mémoires d'un Éléphant blanc que, en su momento, fue editada varias veces en Francia, acompañada incluso de ilustraciones, traducida al inglés y publicada en Estados Unidos. La primera parte de Las memorias de un elefante blanco, de la profesora e investigadora del Departamento de Filología Francesa de la Universidad de Salamanca, María Vicenta Hernández Álvarez, presenta la influencia del padre de Judith, Théophile Gautier, y del parnasianismo, así como un recorrido por sus publicaciones en varios géneros literarios insistiendo en aquellas que suponen un antecedente en motivos o formas a las Mémoires, cuya traducción ocupa la segunda parte del libro.

En 2017 se celebró el centenario de la muerte de Judith Gautier quien, al igual que otras escritoras, ha sido redescubierta gracias a homenajes póstumos. Tildar la obra orientalista de Gautier como simple fruto de herencia y modas, sería injusto. Adjudicarle unas alabanzas desmesuradas, o hacer que diga lo que los lectores y críticos de hoy en día quisieran escuchar, son prácticas poco objetivas. Aunque para algunos lectores recuerde a Flaubert o a su propio padre, para otros,

\footnotetext{
* Acerca del libro de María Vicenta Hernández Álvarez, Las memorias de un elefante blanco (Salamanca, Ediciones Universidad de Salamanca, colección "Memoria de Mujer", 2018, 192 p. ISBN: 978-84-1311-153-7).
} 
Judith supera a ambos al pintar con gracia, fuerza y cierta ironía los sentimientos más inherentes al ser humano sin caer en el sentimentalismo.

Fue la primera mujer en entrar a la Academia Goncourt, en 1910, cuando tenía sesenta y cinco años. Produjo obras literarias de todos los géneros que, a pesar de contar con pocas reediciones en la lengua original y escasas traducciones a otras lenguas, se encuentran hoy en Gallica, la biblioteca digital de la BnF. También fue crítica de arte y de música, traductora, escribió libros de viajes y sus propias memorias.

La profesora Hernández Álvarez reconoce que Mémoires d'un Éléphant blanc fue la primera obra de Gautier que cayó en sus manos y, después de conocer el resto, este relato le parece el resultado al que las demás ficciones narrativas quieren llevar: «La "entrada fantástica" a unos contenidos "explícitamente autobiográficos"». El año de publicación de las Mémoires, 1893, coincide con el de su última gran novela histórica y es también el punto de inflexión en la trayectoria de la autora que se sumerge en un proyecto autobiográfico, aunque ensayos, cuentos y teatro la seguirán acompañando hasta sus últimos días. Por ejemplo, a través de puestas en escena simbolistas para su teatro de marionetas, espectáculos que ofreció durante toda su vida en su propia casa, Gautier descubría la parte oculta y onírica de la realidad. Además, siempre mostró admiración hacia la vida nómada e imprevisible de los comediantes, llena de viajes y ficciones.

A partir de los 11 años, Judith contó con libre acceso a la biblioteca de su padre y le ayudó en la preparación del Roman de la Momie. Fue, durante toda su vida, una incansable recolectora de vestigios del pasado amenazados por la civilización moderna. Aprendió chino y persa y tradujo los ciento doce poemas chinos que compondrán Le livre de Jade, publicado en 1867. En su casa no solo se formó en ciencias y arte, sino que también bebió del misticismo y las ciencias ocultas, tan de moda en el París de la época, y se interesó especialmente por el atractivo erótico del andrógino, modelo ambiguo que encarnarán sus personajes masculinos en varias ocasiones. En Le Collier des jours: souvenirs de ma vie, da muestra de sus lecciones de piano, de danza clásica y de su interés por los interesantes personajes que su padre invitaba a casa. Pronto entabla amistades en los círculos literarios y musicales, y a los dieciocho años comienza a escribir en catálogos de exposiciones de arte.

Se casa con Catulle Mendès, un discípulo de Leconte de Lisle, gran representante del parnasianismo que organiza en su casa discusiones literarias y filosóficas a las que Judith también asiste. Se entrega al estudio y la escritura al modo parnasiano, aunque la libertad de formas será en ella una marca de originalidad. La separación de Mendès, que la ignoraba y engañaba y con quién había conocido a grandes genios como Wagner y Hugo, pone fin a su época parnasiana.

En su gusto por las tierras lejanas que nunca visitó, cultivará disciplinas como la antropología, la etnografía o la arqueología. Les Peuples étranges (1879), obra de carácter divulgativo con un formato parecido al "cuaderno de viaje", es buena muestra de sus meticulosas investigaciones. El capítulo tercero, «Un día en el reino de Siam», comentado extensamente en la primera parte de la obra aquí 
reseñada, anuncia algunos de los motivos de Mémoires d'un Élephant blanc. Además, la autora de la traducción nos indica la posibilidad de que Judith se inspirara para las Mémoires en dos obras: Les Mémoires de l'éléphant (1771), de Jean-Henri Marchand, y Voyage dans l'Inde, la Chine, le Japon (1891), de L. Peyrin. En esta última, aparece la presencia del elefante relacionada con la felicidad en el reino de Siam y la encarnación en elefante como etapa intermedia entre realeza y divinidad.

La Conquête du Paradis (1887) -L'Inde éblouie, en su última versión- supuso para Judith 7 años de investigación y 26 de reescritura. Narra la toma francesa de Madrás, influenciada por Las Mil y Una Noches, les Lettres Persanes de Montesquieu, Zadig de Voltaire y varios textos védicos. En esta novela histórica, aparecen varios elefantes que son la encarnación de Ganesha, dios de la sabiduría que simboliza el éxito, el poderío y la protección. Además, deja ver la concepción dual del amor que tiene la escritora: cortés y romántico, por un lado, dominador y angustioso, por otro. En este sentido, el aislamiento del mundo y la espera inactiva de los personajes femeninos revelan cierta igualdad entre las mujeres orientales y occidentales. Incluye también escenas pedagógicas en la descripción informativa y poética de todo tipo de realidades a través de informantes sabios e informados ignorantes y agradecidos. Además, la narración de cruentas batallas épicas se entremezcla con grandes dosis de humor e ironía.

Estas dos obras servirán para la génesis de Iravata, el elefante blanco que escribe sus memorias, publicadas en 1893 como un cuento para niños. Si su estilo sencillo hacen a las Mémoires aptas para todas las edades, su lectura no resulta tan fácil, ya que presenta varias capas: la informativa, la entretenida, la pedagógica, la exótica, la erótica, la violenta, la mística, etc. En este formato, la autora sigue empeñada en combinar la historia, la documentación y la vida cotidiana con la ficción y lo extraordinario. Aunque se mueva en otros tiempos y espacios, el amor trágico está presente en todas las civilizaciones: un amor en lucha contra tradiciones o poderes opresores que condiciona a los héroes y desencadena escenas crueles y violentas que no pierden en belleza.

Cuando el elefante blanco estaba aprendiendo a escribir, todos esperaban que anotara revelaciones sobre las transmigraciones del alma de rey que ocupaba su cuerpo, pero, en lugar de ello, redactará sus memorias. En la infancia, había sufrido rechazo por parte de su manada, ya que era el único albino y, en cautividad, aprendió a someterse, obedecer y resignarse para no volver a pasar hambre o sed, en su faceta más instintiva, y para no añorar nunca más la libertad perdida, en su faceta espiritual. Orgulloso de ser tratado como un buen augurio para el reino, señal de felicidad, victoria y prosperidad, se fue olvidando de lo que eran las aventuras de la vida salvaje, cambiadas ahora por una monotonía indolente.

Su dueña lo entiende, su mahout o cuidador le muestra sus sentimientos y en su nuevo dueño llega a ver un amigo a quien proteger. Sin embargo, en algunos momentos, Iravata se muestra consciente de su naturaleza salvaje al darse cuenta de que piensa sólo en sí mismo, de que es esclavo de su enorme apetito. Llega a matar a traición, tal y como aprendió de los hombres, con fiereza salvaje, pero 
también con humana valentía, entrega y heroísmo, lo que le permite liberar al príncipe y conseguir su propia libertad: ya no tendría cuidador. Así, siente que lo han elevado a la dignidad del ser humano. Sin embargo, en la nueva condición, el elefante será esclavo de Parvati, hija de sus amos; esclavitud que, paradójicamente, representa para él el paraíso. La aceptación, la complicidad, el aprendizaje, los diversos juegos y placeres con la niña nos muestran una sólida relación de amistad cargada de erotismo.

La metaliteratura está presente en el libro, no sólo porque con sus referencias la autora nos invite a revisar su obra completa o los textos europeos y védicos en los que se inspira, sino porque se narran dos fábulas a lo largo del relato, una en boca del elefante y otra enunciada por el anacoreta que Iravata y Parvati encuentran cuando se fugan a la selva. La educación de la niña en su casa, al igual que la de Judith, fue muy variada: música, danza, escritura y poesía, y sirvió también al elefante, que aprendió así la fábula que transcribe en el libro de sus memorias y que trata sobre la desconfianza que nos permite no sucumbir al engaño de los desconocidos.

En palabras de la traductora, el deseo más auténtico de Judith queda plasmado, mejor que en sus escritos autobiográficos como Le Collier des jours, en obras de ficción como las Mémoires. El empeño del elefante blanco en olvidar su paraíso original, salvaje y libre en los bosques de Laos, y conformarse con el paraíso artificial del presente puede significar para Judith y sus lectores la necesidad de un refugio exótico, de un paraíso lejos de la vulgaridad y la fealdad de la vida moderna: moderación y serenidad, para los héroes masculinos; aceptación, resignación y sacrificio para las figuras femeninas. Este es el camino de aprendizaje que Judith propone en sus obras, el único paraíso posible.

En esta ficción, la utilización del elefante no es baladí. Por un lado, el que sea blanco permite a la estudiosa Judith introducir el tema de la reencarnación, presente en el hinduismo y el budismo imperantes en los territorios representados. La veneración que profesan algunos pueblos a dicho mamífero se debe a la creencia de que el alma de los reyes transmigraba a este nuevo cuerpo antes de la última reencarnación de los mismos en una deidad. Así, se incorpora también la connotación cultural y supersticiosa de que el elefante representa un buen augurio, el éxito y la prosperidad del reino al que pertenece.

Por otro lado, el elefante del relato es susceptible de educación y mejora. Le resulta difícil escuchar y entender, pero más aún comprenderse a sí mismo y hacerse entender: si sus barridos y pataleos asustan y su movimiento de orejas simboliza alegría, sólo su escritura muestra el deseo de amistad, ternura y pasión que no puede expresar de otra manera. Al final del cuento, Iravata parece haber conseguido, sin otorgarle mucha importancia, aquello que Judith tanto apreciaba: la vida viajera del comediante. A pesar de no haber viajado demasiado, la escritura será para la autora el mejor vehículo de transporte. Al igual que el elefante, que accede fortuitamente a la sabiduría de los brahmanes aprendiendo así a escribir, Judith tiene acceso desde muy pequeña a grandes privilegios tales como la biblioteca y los contactos de su padre. De esta manera, se entrega de por vida al estudio 
y la escritura, buscando refugio en mitos, en leyendas y en viajes ficticios a lugares lejanos.

A través de una audaz elección del léxico, la profesora Hernández Álvarez promueve un viaje al glorioso pasado de las grandes civilizaciones del sudeste asiático, destinado a los lectores hispanohablantes que aún no dominan la lengua de Molière. Los recursos utilizados para transmitir imágenes nítidas y plásticas de la arquitectura y los decorados de dichos lugares son, entre otros, las metáforas, la écfrasis, las enumeraciones exhaustivas o las descripciones pormenorizadas del lujo y el adorno que se mantienen escrupulosamente en la traducción. Tampoco echamos de menos la gracia, la fuerza y la ironía que caracterizan el lenguaje literario de Judith, ya que la traducción se sirve también de ellos para representar los sentimientos humanos más profundos.

Además, nos gustaría resaltar el gran trabajo de documentación realizado por la traductora que, sin duda alguna, habrá debido indagar en la mitología y filosofía hindú, así como en las costumbres de la vida cotidiana, desde los atavíos personales hasta las fiestas y el marco arquitectónico en la que se desarrollan las diferentes escenas.

$\mathrm{Si}$, como queda dicho, esta obra de ficción se acerca más que ninguna de las autobiográficas a la verdadera Judith Gautier, se hace más que recomendable no sólo la lectura del original, de ser posible, sino también de la traducción al español, así como del excelente estudio preliminar con que cuenta la edición de María Vicenta Hernández Álvarez, en esta su primera versión en castellano.

\section{REFERENCIAS BIBLIOGRÁFICAS}

MARCHAND, Jean-Henri (1771): Les Mémoires de l'éléphant, écrits sous sa dictée et traduits de l'indien par un Suisse. Amsterdam / París, J. P. Costard.

PEYRIN, Laurence (1891): Voyage dans l'Inde, la Chine, le Japon. Mours, usages et coutumes des peuples de ces contrées. Tours, Alfred Cattier Éditeur. 